\title{
Investigation of the Relationship between Taking Power and Wealth of Barmakian in the Abbassi Caliphate System with their Fate
}

\author{
Tooba Arabameri \\ Payame Noor University (PNU), Tehran, Iran
}

Doi:10.5901/mjss.2015.v6n6s6p126

\begin{abstract}
Iranian Barmakian were appointed as cabinet minister in the court of the Abbassi caliphate. And according to the importance of Iranian influence in the court of the Abbassi caliphate, they caused the development of administrative, economic, educational institutions. Caliphs' looks to ministers who their destiny marked by their impressive power is remarkable. This research has been formed in a descriptive method. The main purpose is investigating this issue by using library research and use of systematic resources and studies.
\end{abstract}

Keywords: Abbassian, Ministers, Barmakian, Power, Wealth

1. Did the Iranian Ministers Able to Create Administrative, Military, Financial Developments, etc... in the Abbassian Caliphs' Court?

\subsection{Are the knowledge and skills of Iranian ministers associated with their destiny?}

Ministry in the Abbassian period of Abbassi caliphs in order to extend their power took steps to develop their administrative organization. To imitate the Iranian, ministry position was recognized as one of the major institutions of the state and they even considered the low-level ephemerality and extinction of the Umavian due to the absence of Iranian and civil service employment and they gave the responsibility of Ministry and governmental jobs to Iranians. In other hand, they could not trust Arab tribes so they turned to the Iranians and Iranian customs. Ministry was divided into two types of the delegation which was counted as the plenipotentiary representative of the caliphs in performing all public and governmental affairs. Enforcement ministry were merely notified orders and judgments of the caliph's to peasants, rulers and governors. (Klosens, 2002, 63-59).

\section{Barmakian}

A few comments stated about the Barmakian and Nobahar temple:

1- That was one of the property of Fars and Persian kings and they were attended to the temple of Balkh Nobahar and they were Magian.

2- Barmakian are originally Iranian and they were responsible for them and had the supervisory of Nobahar which was the high place in Balkh all that long pre-Islamic period.

3- Barmakian were idolaters, when they became familiar with the name of Mecca and the Kaaba in Balkh high places, they built a temple like Kaaba. There were idols in that place, he stated that Nobahar is almost the same as the new spring and it was respected by Iranians and Kaniri's pilgrims who came from remote areas and covered the walls of the temple by precious textiles.

4- In the meantime also have been mentioned of fairy tales, for example:

Lohrasb is the fourth king of Kinian, when he gave his throne to his son Goshtasb, he himself went to the temple of Maromy that God worshipers of those days were considered that respectable that the Mecca's honorable Arabs were respecting that. He worshiped God in piety final thirty years of his life. However, it should be noted the fact that Lohrasb is Iranian and Zoroastrianism and he was the Nobahar of the temple.

5- Sulayman ben Abodol Malik wanted to select a minister for himself so he chose Khalidebne Barmak. Khalid was born in $710(A D)$ and Sulayman ben Abod al-Malik was died in 717 (AD).

6- Nobahar is a temple that Manuchehr built it for the calendar of month that he had hung over the green silk on the top of it and the abbot and the guards and Saran of Nobahar had the title of Barmak and they were obeyed upon the office properties and lands of temple with Barmak and kings. And Buddhists also made legendary 
events just like Iranians and called its name Nova Viharah which means the new temple and said that first king of the country, was founded a great temple in Balkh and worshipped it until he has died.

7- Salman writers basically believe that Barmak is the new Barmakian ancestor and Barmakian in Iran had the ministry position, and some believe that Sulayman Benn Abdo al-Malik, had set Khalid Barmak as minister. It also stated that Ja'far Barmaki was the Barmakian ancestor of the Bani Ommaye and kind of coins were minted parsley for him by his name Jafari.

Ministry positions have been used for 80 years in their house and their families. Even those are considered as the descendants of Persian kings, but there are various opinions on this issue that the destruction of the temple in Balkh, "Nobahar" is at the time of Uthman or have occurred in the Umavian period.

According to these sayings, traditions and the differences that whether Nobahar or Buddhist temple was a place of idolatry or they called Barmakian by various names and they even show signs about Islam and they have differences of opinion on entering the court of Omavian. In general, in these traditions there is a unity that the Barmakian were Iranian and had religious authorities in Balkh province, and this was converted to Islam and were influential in the court of the Umavian and Barmak's children could find their way toward Abbasian temple. (Khezri, 2004.58; Hosseini, 1972, vol. 2, 241-232, Buddha, 1950, 46-29)

8- Barmak was not a personal name but it was a hereditary title of great priest in the temple of, "Nobahar" near the Balkh, in which there were also temple lands in it, which was in the hands of Barmakian. And a large and prosperous village (mental) in Balkh were in the hands of Yahya bin Khalid bin Khalid. Its Sanskrit name is nova vihara (late modern). This temple was Buddhist, travelers and historians and geographers had controversial ideas about this issue that if this No Bahar is a temple or idol worshipping or places of worshipping fire. And even the foundation of the temple have been attributed to the ancient kings of Iran.

Ministers and priests of the temple were selected from the descendant of the Sassanian Empire. Temple of No Bahar at the time of Moavie was destroyed after the year of $42 \mathrm{AH}$. (Barthold, 1978, 87).

\section{Khalid Ibn Barmak}

Khalid was born in the year of $92 \mathrm{AH}$ and historians have praised him with high attributes and great character. He also had expertise in medicine. He has had a great position between the Umavian caliphs, at the time of the Umavian Mervay (the last Umaavian caliph) he went with Qahtabeh bin Shabib to war with the rulers of the Iraq. Meanwhile, he joined the Abu Muslim who was uprising in favor of the Abbasian. He gained the attention of Saffah Abbassi. Saffah in the year of 134 (AH.) tribute the financial court (Ministry of Finance) to Khalid. He was practically Khalifa's minister. This was the same position he has had in the Mansour Abbasi period. He achieved the Tabarestan and Movasel state government and destroyed "Masmghan" kingship which was in the vicinity of Damavand. (Buddha, 1957, 56-49; Hosseini, 1975.2, 241 232; Khezri, 2003, 58).

\section{Ministry Department of Yahya Barmaki}

Yahya was born in the time period of the reign of Yazid in 115 or $119(\mathrm{AH})$. In the year of $158(\mathrm{AH})$ he was appointed as a ruler to govern the Azerbaijan and Armenia. He was the coach and teacher of his son Harun al-Rashid at that time of Mehdi caliph. He was responsible for his education for 4 to 5 years. Yahya in the year of 162 (AH) was in charge of Divan of Jaish and the Court of Resalat and he was the chief commander of the whole missions. When Haron had all the kingships and rules of the west and Azerbaijan, he was appointed the court of Resalat to Yahya. When Hadi came to the caliph, Haron al-Rashid was the minister and he wanted him stripped of his crown and got his allegiance for his son Jafar but yahya disagreed, imprisoned Haron and Yahya and eventually Harun became the Caliph after Hadi and selected Yahya as secretary minister. Court of Justice and the mission (Adl and Resalat) was in the hands of Yahya. The climax period of Yahya was when he the conquest countries and extended them. The way of governing country in the half of Barmakian was based on the effort and work on country governance and liberality, wisdom and power. Arab civilization with the help of Yahya and his sons came to the existence of God. Yahya had 4 sons, Fazl and Jafar had the position of ministry and his two other boys named Moses and Muhammad could not get to the Ministry department, but they had courtier jobs. Yahya was a fan of science and encouraged scientists, artists and philosophers. He was always engaged in philosophical discussions. He was the first person who ordered to ministers that to name those envelops that issued to the Court in his name. In the case that before it was issued by the caliph. Eventually, Yahya gets old. He gave the ministry to Fazl but two years later Haron gave it to Jafar. (Barthold, 1975, 81-63; Hosseini, 1970, 2241-232; Balkhi, 1996, Jz'3-2-1, 453-452; Taqush, 2000, 104-101). 


\section{Fazl Barmaki}

He was born in the year of $148(\mathrm{AH})$, seven days before the Harun al-Rashid and he was the foster brother of Harun alRashid. He headed the shrine at the time of his father's ministry, he was appointed as the teacher of Amin Abbas. He governed the Khorasan and state governments of Georgan and Tbarestan, Jebal, Armanie and Ghos and Ray and Damavand in his realm. He destroyed the revolt of Yahya bin Abdullah Alawi, the brother of Deylam. Fazl was called as a minor minister and had great campaigns to Iran. He was the first person who install lights and lanterns in the mosques in the Ramadan nights. Eventually, Haron take him back to Baghdad in the year of 180 (AH) Haron sealed his caliphate and gave it to Jafar. Fazl had two sons, by the name of Abbas and Abdullah that in the time of Mamun they had office jobs. (Ferrari, 1985, 4, 64, Buddha, 1955, 98-85; Masoudi, 1975, 328; Beihaghi, 1990, 415-414).

\section{Jafar Barmaki}

Ja'far ibn Yahya was born in Medina in the year of $150(\mathrm{AH})$. He was an eloquent, knowledgeable, competent manager and distinguished calligrapher, on board and involved in astronomy.

His description of services and jobs are considerable. At first the government of Egypt, a commander who was tasked to suppress Syrian rebel and he was successfully completed it and gained ministry position.

He was president of the whole government and had the management and all of Empire state issues and jobs. Haron sealed the kingship from him a few months after gave it to his father and appointed him as the governor of Khorassan and Sijistan. Also he had responsible for the bodyguard commander of the Khalifa, even his name was minted on the coin, Khalifa got him another job that Khalifa appointed Amin and Mamun the next crown prince and Ma'mun served as governor of Khorassan to Hamadan, Jafar was awarded this job, of course he did not govern there practically and he always sent his guys to different states and he himself was living in Baghdad.

(Buddha, 1957, 103- 101)

Finally, in the year of 187 (AH) Haron got angry against Barmakian and killed Jafar and seized all their property except Mohammad Khalid Barmaki and imprisoned Yahya and Fazl. (Balkhi, 1995, c. 3.2 1, 453-452; Beihaghi, 1991 , 193; Mostofi, 1983, 306; Tabari, 1995, vol. 12, 5308-5297).

\section{The Causes of the Fall of Barmakian}

Several reasons mentioned for the fall of Barmakian by historians in the book of Rozalsafa that Yahya bin Abdullah Alawi imprisoned by Haron in the jafar Ibne Barmaki's house but Jafar released him and the spy sent attributed this news to Fazl ibn Rabi and he informed Haron and Haron got anger against Barmakian. Jafar also built a house that Haron spent 20 million on it and Haron got angry on this issue. In the history book of the Abbasian caliphate, it was noted from start to end of Alle Buye (Buye family) that the accumulation of wealth, power, glory, rivalry and jealousy of Arab leaders, was concerned Khalifa. Even Harun al-Rashid was forced to tell it to yahya to take the money and he felt that he has had him in the caliphate, just as it is. And in the book of Tabari history and date selection has mentioned about the marriage of Harun al-Rashid sister Abaseh with Jaffer. And in the book of Barmakian, they considered the crowning glory and power and wealth, as the main cause of death of Ja'far Ibn Yahya which its reason was because they have found that they have magnificent buildings. Harun sent a person to the castle of Ja'far ibn Yahya to search the Caliph, and he said it to khalifa that those who went to visit the caliph they went to Ja'far ibn Yahya before it. Courtiers had so much jealousies upon the Barmakian and Fazlebne Rabi, he introduced Zeradeh bin Mohammed Al Arabi who was great at speech with eloquent and elegant culture to Haron and then with the efforts of courtiers and their jealousies, he has achieved vice positions of Jafar. And people like Fazl ibn Rabi Ali 'bin Isa bin Mahan continued to slander and calumny against Barmakian. On the other hand in this book their strict passion was skeptical toward Islam, charged them about that they attached to the Iranian old religion and sometimes called them atheists and free thinking and disbelieving. And these allegations were not ineffective in leader's mind. From other causes that historians have mentioned less about them, Musa ibn Yahya had the main role of rebellion and revolution in his head and one of the relatives of the Khalifa bin said many people really consider Musa ibne Yahya as a real Imam and they give him one fifth of its assets. Barmakian did not like Haron hostility towards Alavian. And had a secret meetings with Shia leaders and spies and corrupt people and envious of the Arabs delivered this to the caliphs. The malice and malevolence of Zubaydah, the mother of the Amin could be the reason for supporting the Barmakian from Mamun and complicity of Arab rulers like al-Rabi and Ale Mazid that had been weakened by the Barmakids influence so they were complicit with Zubaydah. Barmakian had so much power that minted coins as their names and minted coins called Yahya in the Muhammadiyah, in the year of $173(\mathrm{AH})$ and golden coin were minted 
which were called Jaafar in the year of $184(\mathrm{AH})$ and silver coin also called by the name of Jaafar. Finally Haron gave great importance to these rumors, and all agreed on the killing of Jafar after Haron return from Mecca .He killed himself and Fazl, and Yaya and his son Muhammad were imprisoned. (Balkhi, 1995, c 3-2-1, 453-452; khezri, 2001, 60-58; Tabari, 1995, vol. 12, 5297; Tabari, 1983, 306-305; Buddha, 1957, 138-112; Zidane 1985, 789)

But with the fall of the Barmakian its consequences became apparent, because since then Haron caliphate declined and weakened. And all people considered his behaviors ugly, and there was insurgency in Khorasan, Haroon went there to calm Khorasan and in choosing Amin and Mamun which its racial aspect is also important and mamun, who was in the East, had a Iranian mother and because he was empowered, Barmakian considered him and gave the responsibility of the West to Amin, including Iraq and Syria. First Yaya and Fazl were imprisoned in Rafeqeh near the old Raqqa. However, but after a few months on charges of conspiracy of Abdul Malik bin Saleh take them to the Al-Aqasi deputy and jailed them and punished them with great intensity and violence, and finally Yahya was died in 190 (AH) suddenly. And Fazl got tongue paralyzed and he was healed by the help of Amin. And ultimately paralyzed his tongue and half of his body. He was died in the year of $193 \mathrm{AH}$.

And about the Mohammad Khalid they did not know about the date of his death. But there were differences of opinions about the marriage of Abaseh and Jafar and substitution of one or two or three boys, and even the killing of Abaseh was controversial and even many legends are listed about the killing of the sons of Ja'far ibn Yahya and Abaseh. (Buddha, 1336, 180-141).

\section{Conclusion}

Barmakian competency was obvious in the government of the country in terms of administrative, military, economic, and scientific on Khalifa and public. Several factors mentioned in historical sources each one of them individually could not destroy Barmakian. But they all came together. So khalifa extend the power and glory of himself. Destroy the failure possibility to eliminate Iranian ministers. The extent of power and wealth, combined with hostility and slander of Barmakian and complicity of the courtiers, Arab tribes and mother of Amin. Finally, Harun al-Rashid Abbassi ignored the valuable services of Iranian ministers and was waiting for an opportunity to destroy Barmakian.

\section{References}

Barthold, V.v, caliph and sultan, interpreter: Cirrus Izadi, Amir Kabir Publications, 1982

Balkhi, Mohammad Khavand King, Rozeh Alsafa, Academic Press, 1995

Buddha, leucine, Barmakian, Translator Abdul Hossein Maikde, The Translation and Publication, 1985

Beihaghi, Abolfazl, the history of Beihaghi, Khaju Press, 1990

Khezri, Ahmad Reza, the history of the Abbasian caliphate from start to finish of Ale Buwae, the publisher, 2001

Hosseini, Ghiyasuddin, Habib Express, Khayyam publication, 1982

Zidane, Georgie, the history of Islamic civilization, interpreter Ali Javahery Kalam, Amir Kabir Publishing, 1985

Tabari, Muhammad ibn Jarir, the history of messengers, translator Hoajttolla Juadki, mythology Press, 1995

Taqoosh, Mohammad Sohail, like Abbasi, translator H. Joudaki, Press Institute of Science, 2000

Ferrari, R.n, history of Islam to the competency, translator: Hassan Anushe, Amir Kabir Publishing, 1982

Klosens, Carla, Introduction to the bureaucracy in Iran, translated by James Azhand, Asatir Press, 2002

Tabari, Hamdolla, date selection, Translator Abdul Hussein Navoi, Amir Kabir Publications, 1982

Masoudi, Ali bin Hussein, A'l-tanbihat and Alashraf, Abolghasem Payandeh translating publishing and Book firm Publishing 1970 